\title{
MENINGKATKAN HASIL BELAJAR PESERTA DIDIK MELALUI MEDIA VIDEO PEMBELAJARAN PADA PEMBELAJARAN JARAK JAUH DI MASA PANDEMI COVID-19
}

\author{
NORMA \\ SMP Negeri 1 Nunukan \\ Email: nomaputri33@gmail.com
}

\begin{abstract}
ABSTRAK
Tujuan dari kajian pustaka ini adalah ; (1) Untuk menciptakan kondisi belajar yang nyata terhadap peserta didik di masa Pandemi Covid-19; (2) Untuk mengetahui peran media video pembelajaran dalam proses pembelajaran Jarak Jauh; (3) Untuk mengetahui pengaruh antara penggunaan media video pembelajaran terhadap hasil belajar peserta didik di masa Pandemi Covid-19. Kajian ini menggunakan metode penelitian kuantitatif. Hasil kajian ini menunjukkan bahwa : (1) Terselenggaranya proses belajar jarak jauh di masa Pandemi Covid19 melalui video pembelajaran. Hasil data yang menunjukan terselenggaranya proses pembelajaran bedasarkan tingkat kehadiran peserta didik $94 \%$ dan hasil data pra media video pembelajaran khususnya pada minat pelajaran IPS sebesaar $42 \%$ setelah menggunakan media video pembelajaran meningkat menjadi 77\%; (2) Media video pembelajaran dapat membantu guru menyampaikan materi dan menciptakan situasi pembelajaran yang tidak monoton. Hasil data pra media video pembelajaran yang menunjukan media video pembelajaran dapat membantu guru menyampaikan materi sebesar $42 \%$ dan setelah menggunakan media video pembelajaran meningkat menjadi 94\%; (3) Media video pembelajaran dapat membantu peserta didik untuk memahami materi pelajaran dan menyelesaikan tugas yang di berikan guru. Data hasil pra media video pembelajaran yang menunjukan peserta didik dapat menjawab pertanyaan melalui pembelajaran daring sebesar $19 \%$ setelah menggunakan media video pembelajaran meningkat menjadi 94\%; (4) Media video pembelajaran yang layak dan efektif dalam meningkatkan motivasi dan hasil belajar bagi peserta didik dimasa Pandemi Covid-19. Hasil data pra media video pembelajaran yang menunjukan materi pelajaran yang diberikan kepada peseta didik melalui daring sangat jelas sebesar $42 \%$ setelah menggunakan media video pembelajaran meningkat menjadi $94 \%$.
\end{abstract}

Kata kunci : Media video pembelajaran, masa Pandemi Covid-19, hasil belajar peserta didik.

\section{ABSTRACT}

The objectives of this literature review are; (1) To create real learning conditions for students during the Covid-19 Pandemic; (2) To find out the role of learning video media in the distance learning process; (3) To find out the effect between the use of learning video media on student learning outcomes during the Covid-19 Pandemic. This study uses quantitative research methods. The results of this study indicate that: (1) The implementation of distance learning processes during the Covid-19 Pandemic through learning videos. The results of the data showing the implementation of the learning process based on the student's attendance rate of $94 \%$ and the results of the pre-learning video media data, especially on the interest in social studies lessons by $42 \%$ after using the learning video media increased to $77 \%$; (2) Learning video media can help teachers deliver material and create a learning situation that is not monotonous. The results of pre-learning video media data showing that learning video media can help teachers deliver material is $42 \%$ and after using learning video media it increases to 94\%; (3) Learning video media can help students understand the subject matter and complete the tasks given by the teacher. The data from the pre-learning video media showing that students can answer questions through online learning is $19 \%$ after using the learning video media, increasing to 94\%; (4) Appropriate and effective learning video media in increasing motivation and learning outcomes for students during the Covid-19 Pandemic. The results of pre-learning 
video media data showing the subject matter given to students online are very clear at $42 \%$ after using learning video media, increasing to $94 \%$.

Keywords: Learning video media, the Covid-19 pandemic, student learning outcomes.

\section{PENDAHULUAN}

Munculnya Pandemi COVID-19, sangat berpengaruh pada dunia Pendidikan terutama pada pelaksanaan kurikulum 13 berubah menjadi kurikulum secara khusus. Hal ini sebagaimana di jelaskan dalam Peraturan Menteri Pendidikan dan Kebudayaan Republik Indonesia Nomor 719/P/2020 tentang Pedoman Pelaksanaan Kurikulum pada Satuan Pendidikan dalam Kondisi Khusus, pelaksanaan kurikulum 13 berubah menjadi kurikulum secara khusus. Dengan diberlakukannya Peraturan Menteri Pendidikan dan Kebudayaan Republik Indonesia Nomor 719/P/2020 ini, maka pola pembelajaran sudah tidak lagi sepenuhnya menggunakan sistim tatap muka (Luring) namun berubah menjadi belajar dari rumah atau Pembelajaran jarak jauh dalam jaringan (Daring). Perubahan sistim kurikulum khusus sangat mempengaruhi sistim pembelajaran pada dunia Pendidikan baik guru maupun peserta didik di daerah yang terdampak COVID-19. Dengan diterapkan peraturan tersebut, maka seluruh sekolah-sekolah yang ada di Indonesia baik ditingkat Provinsi maupun di tingkat Kabupaten/Kota sudah menerapkan kurikulum secara khusus. Tidak terkecuali Kabupaten Nunukan sebagai daerah yang berada pada posisi perbatasan Indonesia-Malaysia, juga berimbas pada perubahan sistim kurikulum khusus.

Dimasa Pandemi COVID-19, peserta didik dianjurkan belajar dari rumah atau Pembelajaran jarak jauh dalam jaringan (Daring). Hal ini berdasarkan Kementerian Pendidikan dan Kebudayaan Republik Indonesia mengeluarkan Surat Edaran Nomor 4 Tahun 2020 Tentang Pelaksanaan Kebijakan Pendidikan Dalam Masa Daruat Penyebaran Coronavirus Disease (COVID-19) yaitu bahwa proses pembelajaran dilaksanakan dari rumah. Hal yang sama juga ditegaskan dalam Surat Edaran yang dikeluarkan oleh Kementerian Pendidikan dan Kebudayaan Nomor 15 Tahun 2020 tentang Pedoman Penyelenggaraan Belajar Dari Rumah Dalam Masa Darurat Penyebaran Covid-19. Menurut Saragih (2020) bahwa pembelajaran Daring merupakan pembelajaran yang dilakukan secara online antara guru dan peserta didik.

Belajar dari rumah atau Pembelajaran jarak jauh dalam jaringan (Daring) merupakan salah satu pilihan yang ditetapkan oleh Pemerintah dalam kondisi pencegahan penyebaran COVID-19. Tujuan dari pelaksanaan belajar dari rumah atau Pembelajaran jarak jauh dalam jaringan (Daring) adalah memastikan pemenuhan hak peserta didik untuk mendapatkan layanan pendidikan selama darurat COVID-19, melindungi warga satuan pendidikan dari dampak buruk COVID-19, mencegah penyebaran dan penularan COVID-19 di satuan pendidikan dan memastikan pemenuhan dukungan psikososial bagi pendidik, peserta didik, dan orang tua. Meskipun belajar dari rumah atau Pembelajaran jarak jauh dalam jaringan (Daring) merupakan solusi pemerintah dalam proses pembelajaran di masa Pandemi COVID-19, berbagai masalah yang dihadapi sering terjadi baik kepada guru maupun kepada peserta didik. Salah satu masalah yang sering dihadapi dalam proses pembelajaran dari rumah (Daring) adalah banyaknya peserta didik sulit memahami materi pelajaran tanpa tatap muka, banyaknya tugas yang diberikan kepada peserta didik tidak tuntas, kurangnya dukungan orang tua sebagai pengganti guru di rumah dalam memberikan memotivasi belajar terhadap anak-anaknya, ketidakmampuan orang tua dalam mendapingi anaknya belajar dirumah, waktu pelaksanaan pembelajaran yang lebih singkat. Permasalahan secara teknis seperti lemahnya jaringan internet yang mempengaruhi lambatnya penyampaian tugas yang diberikan kepada peserta didik, demikian juga sebaliknya lambatnya penyampaian hasil tugas dari peserta didik. Disatu sisi mata pelajaran yang disampaikan oleh guru adalah mata pelajaran Ilmu Pengetahuan Sosial (IPS) merupakan mata pelajaran yang memerlukan penjelasan yang lebih detail. Hal inilah yang membuat hasil belajar peserta didik di masa Pandemi COVID-19 cenderung menurun.

Untuk mencapai tujuan pembelajaran dengan memperoleh hasil yang maksimal kepada peserta didik dimasa Pandemi COVID-19, guru dituntut untuk memiliki inovasi dalam 
menggunakan teknologi. Dukungan teknologi informasi dan komunikasi, khususnya internet dan ponsel HP, memungkinkan untuk belajar dengan jarak jauh (Daring). Salah satu inovasi yang tepat dimasa Pandemi COVID-19 adalah dengan menggunakan media video pembelajaran. Melalui media video pembelajaran diharapkan peserta didik tetap menerima dan tertarik untuk terus memahami materi pelajaran melalui media video pembelajaran secara jarak jauh (Daring). Peserta didik dapat melihat materi pelajaran yang disampakan oleh guru mata pelajaran secara berulang-ulang di media video pembelajaran, membantu peserta didik dalam memahami materi pelajaran IPS, menerima materi pelajaran untuk menyelesaikan tugas-tugas yang diberikan oleh guru. Salah satu media yang tepat dalam meningkat hasil belajar peserta didik dimasa Pandemi COVID-19 adalah dengan menggunakan media video pembelajaran secara jarak jauh (daring). Media sangat berfungsi untuk merangsang perhatian dan minat siswa peserta didik pada proses pembelajaran secara jarak jauh (daring). Hal ini sebagaimana yang diungkapkan oleh A Cahyadi (2019) bahwa media adalah segala sesuatu yang dapat dipergunakan untuk menyampaikan suatu pesan (massage) dalam proses belajar mengajar sehingga dapat merangsang perhatian dan minat siswa. Hal senada diungkapkan oleh Yulia (2015:76) bahwa media berfungsi untuk merangsang peserta didik dalam proses pembelajaran untuk memperoleh tujuan instruksi dimana informasi yang terdapat didalam media harus melibatkan peserta didik baik dari segi mental maupun dalam bentuk aktivitas yang nyata sehingga pembelajaran dapat terjadi.

Media video pembelajaran adalah media yang menyajikan audio maupun visual yang berisikan pesan-pesan. Hal ini seperti yang diungkap oleh Menurut Cheppy Riyana (2007) bahwa media video pembelajaran adalah media yang menyajikan audio dan visual yang berisi pesan-pesan pembelajaran baik yang berisi konsep, prinsip, prosedur, teori aplikasi pengetahuan untuk membantu pemahaman terhadap suatu materi pembelajaran. Hal senada juga diungkapkan oleh Moh. Ayip S (2003) bahwa Video merupakan bahan pembelajaran tampak dengar (audio visual) yang dapat digunakan untuk menyampaikan pesan-pesan/materi pelajaran. Dikatakan tampak dengar kerena unsur dengar (audio) dan unsur visual/video (tampak) dapat disajikan secara bersamaan. Media vidio pembelajaran dapat digunakan kapan dan dimana saja oleh peserta didik. Hal ini sebagaimana yang diungkapkan oleh Rahmasari dan Rismiati (2013:22) bahwa Video mempunyai tampilan serupa dengan televisi karena menggunakan audio dan visual, yang membedakan televisi mempunyai jadwal khusus sedangkan video dapat diputar kapan saja. Penggunaan media video pembelajaran dapat mempermudah penyampaian pesan kepada peserta didik, dapat mengatasi keterbatasan waktu, dan dapat digunakan secara tepat dan bervariasi. Hal ini seperti yang diungkapkan oleh Cheppy Riyana (2007) bahwa Penggunaan video sebagai media pembelajaran memiliki beberapa tujuan, antara lain : (1) Memperjelas dan mempermudah penyampaian pesan agar tidak terlalu verbalistis; (2) Mengatasi keterbatasan waktu, ruang, dan daya indera peserta didik maupun instruktur; (3) Dapat digunakan secara tepat dan bervariasi. Selain itu, media pembelajaran juga dapat membantu siswa dalam memahami materi. Hal ini sebagaimana yang dijelaskan oleh Anisa \& Yuliyanto (2017) bahwa media pembelajaran dapat membantu siswa dalam memahami materi yang disampaikan serta memperkaya khasanah pembelajaran. Pandangan lain juga menyebutkan bahwa dengan media bisa membuat pembelajaran lebih jelas, menarik, dan interakatif. Hal ini sebagaimana diungkapkan oleh Amanah (2016) bahwa media juga bisa membuat pembelajaran menjadi lebih jelas, menarik, interaktif, dan efisien.

Dari uraian diatas, untuk menciptakan kondisi belajar yang nyata dan meningkatkan hasil belajar peserta didik kelas VII SMP Negeri 1 Nunukan pada mata pelajaran IPS di masa Pandemi Covid-19, maka dapat disimpulkan bahwa untuk meningkatkan hasil belajar peserta didik dimasa Pandemi COVID-19 diperlukan media video pembelajaran. Oleh karena itu, peneliti melakukan penelitian yang berjudul "Meningkatkan hasil belajar peserta didik melalui media video pembelajaran pada pembelajaran jarak jauh di masa Pandemi COVID-19". 


\section{METODE PENILITIAN}

Penulis menggunakan penelitian survey dengan pendekatan Kuantitatif. Penelitian dimana peneliti ingin gagasan, pendapat sekelompok orang tentang isu dan topik tertentu. . Penelitian Kuantitatif adalah suatu metode penelitian yang bersifat induktif, objektif dan ilmiah dimana data yang diperoleh berupa angka-angka, nilai (score) atau pertanyaan yang dinilai dan dianalisis dengan analisis statistik. Penelitian kuantitatif adalah suatu pendekatan penelitian yang secara primer menggunakan paradigma pospositivisme dalam mengembangkan ilmu pengetahuan (seperti pemikiaran tentang sebab akibat, reduksi kepada variabel, hipotesis dan pertanyaan spesifik, menggunakan pengukuran dan observasi serta pengujian teori) menggunakan strategi penelitian eksperimen dan survei yang memerlukan data statistik (Emzir,2007:28). Penelitian pendekatan kuantitatif bertujuan untuk membuktikan pengaruh penerapan model video pembelajaran terhadap hasil belajar peserta didik pada masa Pandemi COVID-19. Sasaran penelitian adalah peserta didik SMP Negeri 1 Nunukan kelas VII G dengan jumlah 31 peseta didik. Fokus mata pelajaran adalah Ilmu Pengetahuan Sosial (IPS).

\section{HASIL DAN PEMBAHASAN}

\section{Pra Pelaksanaan Media Vidio Pembelajaran}

Berdasarkan hasil survei terhadap 31 peserta didik, maka diambil 18 data yang akan disajikan dalam tabel dengan menggunakan rumus :

$$
\text { Persentase (\%) Data }=\frac{\text { Banyak data A }}{\text { Banyak data seluruhnya }} \times 100 \%
$$

Berdasarkan hasil data pra pelaksanaan media vidio pembelajaran bahwa persentase peserta didik yang tidak absen mengikuti pembelajaran daring $6 \%$ dan yang abesen $94 \%$. Persentase peserta didik yang menyukai pelajaran IPS sebanyak $42 \%$ dan yang tidak menyukai $58 \%$. Persentase peserta didik yang mudah mengikuti pelajaran sebelum menggunakan media vidio pembelajaran $42 \%$ dan yang sulit $58 \%$. Persentase peserta didik yang menyatakan pembelajaran sebelum menggunakan media video pembelajaran sangat jelas $42 \%$ dan yang kurang jelas $58 \%$. Persentase peserta didik yang menyatakan pembelajaran sebelum menggunakan media video pembelajaran sangat membantu dalam memperoleh materi $42 \%$ dan yang tidak 58\%. Persentase peserta didik yang sering mengikuti pembelajaran melalui daring 39\% dan yang jarang mengikuti pembelejaran $61 \%$. Persentase peserta didik yang dapat menjawab pertanyaan melalui daring $19 \%$ dan yang tidak dapat menjawab $81 \%$. Persentase peserta didik yang bertanya $81 \%$ dan yang tidak bertanya $19 \%$. Persentase peserta didik yang sulit belajar secara daring $16 \%$ dan yang mudah belajar secara daring $84 \%$. Persentase peserta didik yang didampingi orang tua $42 \%$ dan yang tidak didampingi orang tua $58 \%$. Persentase peserta didik yang menggunakan handphone $94 \%$ dan yang tidak menggunakan handphone 6\%. Persentase peserta didik yang menggunakan laptop (Komputer) $16 \%$ dan yang tidak menggunakan laptop (Komputer) $84 \%$. Persentase peserta didik yang menggunakan kuota belajar $94 \%$ dan yang tidak menggunakan kuota belajar $6 \%$. Persentase peserta didik yang tersedia jaringan wifi di rumah $16 \%$ dan yang tidak tersedia jaringan wifi di rumah $84 \%$. Persentase peserta didik yang menyatakan jaringan internet merupakan faktor permasalahan $94 \%$ dan yang menyatakan jaringan internet bukan merupakan faktor permasalahan $6 \%$. Persentase peserta didik yang menyatakan guru mengajar sesuai tujuan pembelajaran $94 \%$ dan yang menyatakan tidak sesuai tujuan pembelajaran 6\%. Persentase peserta didik yang menyatakan guru mengajar tepat waktu $94 \%$ dan yang menyatakan tidak tepat waktu $6 \%$. Persentase peserta didik yang menyatakan guru merefleksi akhir pelajaran $94 \%$ dan yang menyatakan guru tidak merefleksi akhir pelajaran $6 \%$. Berikut tabel persentase peserta didik pra pelaksanaan media vidio Pembelajaran : 
Vol. 1 No. 2 September 2021, e-ISSN : 2797-8842 | p-ISSN : 2797-9431

Tabel 1. Data Persentase Pra Pelaksanaan Media Vidio Pembelajaran

\begin{tabular}{|c|c|c|c|}
\hline \multirow[t]{2}{*}{ NO. } & \multirow[t]{2}{*}{ URAIAN } & \multicolumn{2}{|c|}{$\begin{array}{l}\text { PERSENTASE } \\
\quad(\%) \\
\text { PERNYATAAN } \\
\text { PESERTA DIDIK }\end{array}$} \\
\hline & & TIDAK & YA \\
\hline 1 & $\begin{array}{l}\text { Jumlah peserta didik yang di absen melalui media video } \\
\text { pembelajaran }\end{array}$ & $6 \%$ & $94 \%$ \\
\hline 2 & $\begin{array}{l}\text { Jumlah peserta didik yang menyatakan Pelajaran IPS pelajaran yang } \\
\text { di sukai }\end{array}$ & $58 \%$ & $42 \%$ \\
\hline 3 & $\begin{array}{l}\text { Jumlah peserta didik yang menyatakan belajar IPS melalui media } \\
\text { video pembelajaran lebih mudah }\end{array}$ & $58 \%$ & $42 \%$ \\
\hline 4 & $\begin{array}{l}\text { Jumlah peserta didik yang menyatakan materi pelajaran yang } \\
\text { diberikan melalui media video pembelajaran sangat jelas }\end{array}$ & $58 \%$ & $42 \%$ \\
\hline 5 & $\begin{array}{l}\text { Jumlah peserta didik yang menyatakan pembelajaran sebelum } \\
\text { menggunakan media video pembelajaran sangat membantu dalam } \\
\text { memperoleh materi }\end{array}$ & $58 \%$ & $42 \%$ \\
\hline 6 & $\begin{array}{l}\text { Jumlah peserta didik yang jarang mengikuti pembelajaran melalui } \\
\text { media video }\end{array}$ & $39 \%$ & $61 \%$ \\
\hline 7 & $\begin{array}{l}\text { Jumlah peserta didik yang dapat menjawab pertanyaan melalui } \\
\text { pembelajaran daring }\end{array}$ & $81 \%$ & $19 \%$ \\
\hline 8 & $\begin{array}{l}\text { Jumlah peserta didik yang bertanya melalui media video } \\
\text { pembelajaran }\end{array}$ & $19 \%$ & $81 \%$ \\
\hline 9 & $\begin{array}{l}\text { Jumlah peserta didik yang menyatakan belajar IPS melalui daring } \\
\text { lebih sulit dari pada belajar secara luring }\end{array}$ & $84 \%$ & $16 \%$ \\
\hline 10 & $\begin{array}{l}\text { Jumlah peserta didik yang di dampingi orang tua saat mengikuti } \\
\text { media video pembelajaran }\end{array}$ & $58 \%$ & $42 \%$ \\
\hline 11 & Jumlah peserta didik belajar daring menggunakan handphone & $6 \%$ & $94 \%$ \\
\hline 12 & $\begin{array}{l}\text { Jumlah peserta didik belajar daring menggunakan laptop } \\
\text { (Komputer) }\end{array}$ & $84 \%$ & $16 \%$ \\
\hline 13 & $\begin{array}{l}\text { Jumlah peserta didik yang menggunakan kuota belajar sebagai } \\
\text { sarana belajar daring }\end{array}$ & $6 \%$ & $94 \%$ \\
\hline 14 & $\begin{array}{l}\text { Jumlah peserta didik yang tersedia jaringan wifi di rumah sebagai } \\
\text { sarana belajar daring }\end{array}$ & $84 \%$ & $16 \%$ \\
\hline 15 & $\begin{array}{l}\text { Jumlah peserta didik yang menyatakan jaringan internet menjadi } \\
\text { faktor permasalahan pada media video pembelajaran }\end{array}$ & $6 \%$ & $94 \%$ \\
\hline 16 & $\begin{array}{l}\text { Jumlah peserta didik yang menyatakan guru mengajar sesuai } \\
\text { dengan tujuan pembelajaran }\end{array}$ & $6 \%$ & $94 \%$ \\
\hline 17 & Jumlah peserta didik yang menyatakan guru mengajar tepat waktu & $6 \%$ & $94 \%$ \\
\hline 18 & $\begin{array}{l}\text { Jumlah peserta didik yang menyatakan guru merfleksi akhir } \\
\text { pelajaran }\end{array}$ & $6 \%$ & $94 \%$ \\
\hline
\end{tabular}

Berdasarkan tabel data diatas, maka hasil pembelajaran setelah dilaksanakan pembelajaran melalui media video pembalajaran secara daring dapat disimpulkan pada tabel dibawah ini :

Tabel 2. Penyebab menurunnya hasil belajar IPS melalui daring

\begin{tabular}{|c|c|c|c|}
\hline NO. & URAIAN & $\begin{array}{c}\text { JUMLAH } \\
\text { PESERTA } \\
\text { DIDIK }\end{array}$ & $\begin{array}{c}\text { PERENTASE } \\
(\%)\end{array}$ \\
\hline 1 & Kurangnya minat peserta didik terhadap Pelajaran IPS & 18 & $58 \%$ \\
\hline
\end{tabular}


Vol. 1 No. 2 September 2021, e-ISSN : 2797-8842 | p-ISSN : 2797-9431

\begin{tabular}{|c|l|c|c|}
\hline 2 & Belajar IPS secara daring lebih sulit dari luring & 18 & $58 \%$ \\
\hline 3 & Penyampaian materi pelajaran melalui daring kurang jelas & 18 & $58 \%$ \\
\hline 4 & Pembelajaran melalui daring sulit untuk memperoleh materi & 18 & $58 \%$ \\
\hline 5 & Jarangnya peserta didik mengikuti pembelajaran melalui daring & 19 & $61 \%$ \\
\hline 6 & $\begin{array}{l}\text { Tidak adanya respon peserta didik terhadap pertanyaan melalui } \\
\text { daring }\end{array}$ & 25 & $81 \%$ \\
\hline 7 & Kurang aktifnya peserta didik yang bertanya melalui daring & 25 & $81 \%$ \\
\hline 8 & $\begin{array}{l}\text { Kurangnya pendampingan orang tua terhadap anaknya saat } \\
\text { belajar secara daring }\end{array}$ & 18 & $58 \%$ \\
\hline 9 & $\begin{array}{l}\text { Keterbatasan jaringan wifi di rumah sebagai sarana belajar } \\
\text { daring }\end{array}$ & 26 & $84 \%$ \\
\hline
\end{tabular}

Dari tabel diatas dapat di analisis bahwa kurangnya minat belajar siswa terhadap pelajaran IPS berasarkan survei data 58\%. Kecenderungan peserta didik untuk suka atau tidak suka terhadap suatu mata pelajaran dipengaruhi juga oleh gaya kognitif yang dimilikinya. Gaya kognitif merupakan kecenderungan yang konsisten cara bereaksi terhadap rangsang dari lingkungan. Hal ini sebagaimana yang dungkapkan oleh Haswan (2006: 30) bahwa gaya kognitif adalah suatu kecenderungan yang konsisten cara bereaksi terhadap rangsang dari lingkungan. Sedangkan menurut Nasution dan Supriyadi (2007: 6) mendefinisikan gaya kognitif sebagai dimensi psikologis yang memepresentasikan konsistensi individual dalam mengumpulkan dan memproses informasi. Belajar IPS secara daring lebih sulit dari luring berasarkan survei data 58\%. Menurut Mulyadi (2010) bahwa kesulitan belajar merupakan suatu kondisi dalam proses belajar yang ditandai adanya hambatan-hambatan tertentu untuk mencapai hasil belajar. Hal yang senada juga disampaikan oleh Subini (2016) bahwa kesulitan belajar merupakan suatu kondisi dimana kompetensi atau prestasi yang dicapai tidak sesuai dengan kriteria standar yang telah ditetapkan, baik berbentuk sikap, pengetahuan, maupun keterampilan. Kesulitan terhadap peserta didik tidak sama, tergantung kemampuan individu dalam menyelesaikan masalah. Disatu sisi, masing-masing peserta didik berbeda cara pendekatan terhadap situasi belajar. Perbedaan inilah yang disebut dengangaya Kognitif. Gaya kognitif yang dimiliki masingmasing individu akan mempengaruhi prestasi belajar. Hal ini sebagaimana yang diungkapkan oleh Putra (2013) dalam penelitiannya bahwa hubungan gaya kognitif dan prestasi belajar menunjukkan bahwa terdapat korelasi positif dan secara statistik signifikan antara gaya kognitif dan prestasi belajar. Penyampaian materi pelajaran melalui daring kurang jelas, berdasarkan survei data 58\%. Sejak masa Pandemi Covid-19 sistem belajar konvensional ke sistem daring. Proses pembelajaran tetap berjalan dan siswa aktif mengikuti walaupun dalam kondisi pandemi Covid-19. Pada pelaksanaan pembelajaran secara daring, guru memberikan pelajaran melalui penyampaian materi kepada peserta didik. Disatu sisi peserta didik dituntut untuk mampu memahami materi pelajaran yang diberikan. Namun kenyataannya bahwa masih banyak peserta didik yang belum mampu menganalisis materi yang diberikan. Hal ini disebabkan karena penyampaian materi yang disampaikan kepada peserta didik hanya sebatas perintah untuk menyimak dan membaca materi yang terdapat pada buku mata pelajaran IPS kelas VII secara daring. Selain itu, sistim pembelajaran yang kurang efektif. Hal ini sebagaimana yag diungkapkan oleh Vitasari (2016) bahwa sistem pembelajaran yang kurang efektif dapat menyebabkan penyampaian materi sulit untuk dipahami. Pembelajaran melalui daring sulit untuk memperoleh materi berasarkan survei data 58\%. Hal ini disebabkan oleh sulit menerima akses jaringan. Jarangnya peserta didik mengikuti pembelajaran melalui daring berasarkan survei data $61 \%$. Penyebab Jarangnya peserta didik mengikuti pembelajaran melalui daring adalah salah satunya kejenuhan. Hal ini sebagaimana yang dijelaskan oleh Astaman (2018) bahwa masalah yang juga kerap menghinggapi peserta didik yaitu kejenuhan belajar. Meskipun waktu yang digunakan untuk belajar cukup lama, akan tetapi hasilnya tidak 
optimal karena kondisi jenuh. Hal ini sebagaimana yang diungkapkan oleh Rahman (2007) bahwa meskipun waktu yang digunakan untuk belajar cukup lama, akan tetapi hasilnya tidak optimal karena kondisi jenuh. Selain jenuh, faktor yangmenyebabkan peserta didik jarang mengikuti pembelajaran secara daring adalah lebih mengutamakan pekerjaan membantu orang tua. Tidak terjadinya respon peserta didik terhadap pertanyaan melalui daring berasarkan survei data 25 peserta didik dengan persentase $81 \%$ dari 31 peserta didik. Penyebab tidak terjadinya respon terhadap pertanyaan yang disampaikan melalui daring adalah dapat dipengaruhi oleh gaya Kognitif Field- Independent (gaya individu) yang cenderung memilih belajar secara individual. Hal ini sebagaimana diungkapkan oleh Ardana (2008: 5) bahwa cenderung memilih belajar individual, merespon dengan baik, dan independen. Kurang aktifnya peserta didik yang bertanya melalui daring berasarkan survei data 25 peserta didik dengan persentase $81 \%$ dari 31 peserta didik. Seyogyanya peserta didik harus lebih aktif dibanding dengan peran guru. Hal ini sebagaimana diungkapkan oleh Herman (2005: 46) bahwa peran peserta didik lebih aktif dibanding dengan peran guru. Meningkatnya hasil belajar pseserta didik tergantung dari keaktifan peserta didik dalam proses pembelajaran. Hal ini sebagaimana dijelaskan oleh Sugihartono, dkk.(2007:76-77) menyebutkan bahwa faktor-faktor yang mempengaruhi hasil belajar salah satunya kurangnya keaktifan siswa dalam pembelajaran seperti bertanya kepada teman atau guru tentang materi yang kurang dipahami. Kurangnya pendampingan orang tua terhadap anaknya saat belajar secara daring berasarkan survei data 58\%. Menurut Musmirotun Khasanah (2021) dalam jurnalnya bahwa faktor penghambat dalam pembelajaran daring di antaranya adalah : (1) Masih ada beberapa orang tua siswa yang tidak memiliki HP android sehingga tidak bisa digunakan dalam pembelajaran daring; (2) Beberapa orang tua siswa memiliki problem kekurangan quota internet dan signal yang tidak mendukung untuk pembelajaran daring; (3) Pendidikan orang tua yang masih terbatas sehingga mengurangi tingkat perhatian orang tua terhadap pendidikan anak-anaknya; (4) Beban pekerjaan yang terlalu banyak di rumah sehingga orang tua tidak bisa maksimal dalam mendampingi anak-anaknya dalam pembelajaran daring. Keterbatasan jaringan wifi di rumah sebagai sarana belajar daring berasarkan survei data 84\%. Wi-Fi merupakan kependekan dari Wireless Fidelity, yang memiliki pengertian yaitu sekumpulan standar yang digunakan untuk Jaringan Lokal Nirkabel (Wireless Local Area Networks- WLAN). Penyebab keterbatasan jaringan wifi di rumah sebagai sarana belajar daring adalah sebagian daya beli orang tua terhadap pemasangn wifi sangat rendah.

\section{Pelaksanaan Pembelajaran Melalui Media Vidio Pembelajaran}

Pelaksanaan pembelajaran melalui daring dilaksanakan pada 3 tahapan, yaitu persiapan, pelaksanaan proses pembelajaran melalui media video pembelajaran, dan analisis hasil. Tahap pertama pada penelitian ini adalah persiapan, yaitu dengan melakukan komunikasi dan koordinasi dengan peserta didik kelas VII melalui media video untuk menentukan waktu pelaksanaan media video pembelajaran. Kemudian guru memulai melaksanakan kegiatan pembelajaran dengan melakukan absensi kepada peserta didik melalui video pembelajaran.

Tahapan kedua pada penelitian ini adalah guru melakukan proses pembelajaran kepada peserta didik melalui media video pembelajaran. Contoh gambar media video pembelajaran seperti pada gambar dibawah ini. 


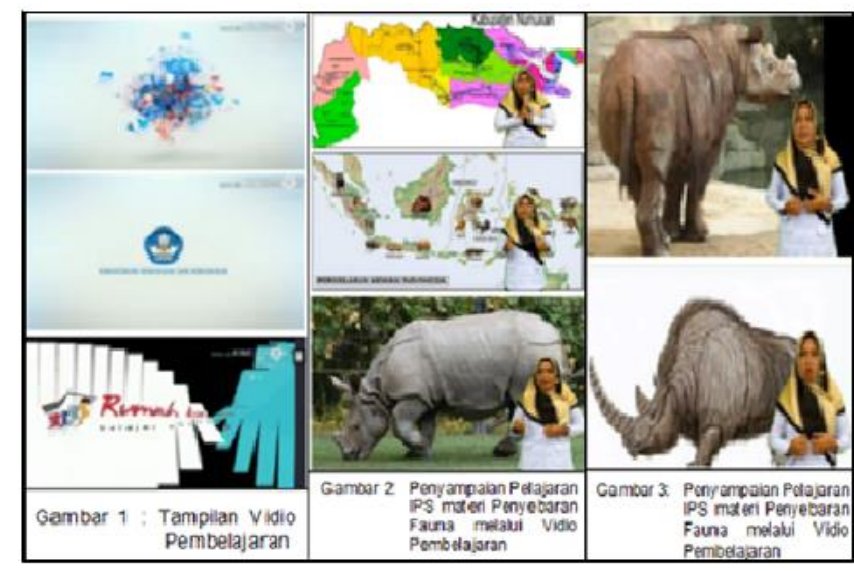

Gambar 1. Media Video Pembelajaran

Berdasarkan data hasil análisis menunjukkan bahwa $94 \%$ menyatakan pelaksanaan media vidio pembelajaran dimulai dengan sedangkan $6 \%$ tidak mengikuti daring. Guru mengabsen melalui gogle form. Google Formulir atau yang biasa disebut "Google Form" atau worksheet dalam pembelajaran adalah salah satu fitur google yang bertujuan untuk mempermudah penggunanya membuat suatu survei/formulir melalui internet. Penggunaan layanan Google Form terdapat 3 metode yaitu mengakses Google Form, merancang Form, dan mengirim Google Form. Menurut Thamrin (2008 :1) Google Form dapat digunakan untuk (1). Absensi online, kuis online, ujian online, survey performa guru, survey masukan orang tua murid, formulir registrasi online; (2). mendorong paperless culture: tidak lagi cetak formulir, semuanya dijadikan online, bahkan tabulasi hasilnya pun otomatis dan sudah online. Pernyataan ini didukung oleh pernyataan Sari (2020) bahwa google form dimanfaatkan sebagai media pembelajaran online. Berdasarkan data hasil análisis bahwa $77 \%$ menyatakan Pelajaran IPS pelajaran yang di sukai atau diminati sedangkan $23 \%$ menyatakan tidak minat atau tidak disukai. Minat adalah kondisi dimana seseorang merasa suka dan tertarik pada suatu hal, tanpa ada yang menyuruh. Hal ini sebagaimana yang diungkapakan oleh Slameto (2015) bahwa minat adalah kondisi dimana seseorang merasa suka dan tertarik pada suatu hal atau aktivitas, tanpa ada yang menyuruh. Sedangkan menurut Edy Saputra (2020) bahwa minat merupakan suatu motivasi instrinsik yang menjadi penggerak seseorang dalam melakukan aktivitas dengan penuh kekuatan. Untuk meningkat minat belajar menurut Darmadi (2017) menjelaskan bahwa salah satunya dengan cara membuat pembelajaran yang menarik. Berdasarkan data hasil análisis bahwa peserta didik yang mudah mengikuti media vidoo pembelajaran $65 \%$ dan yang sulit $35 \%$. Berdasarkan data hasil análisis bahwa $94 \%$ menyatakan pembelajaran melalui media video sangat jelas sedangkan $6 \%$ mengatakan pembelajaran melalui media video kurang jelas disebabkan karena tidak mengikuti daring. Guru harus mampu memilih dan menyusun materi pembelajaran sehingga peserta didik dapat memahami materi yang disampaikan melalui media video pembelajaran. Hal ini sebagaimana yang diungkapkan oleh Mulyasa (2013: 139) bahwa kemampuan mengorganisasikan materi terdiri dari dua tahap, yaitu memilih materi pembelajaran dan menyusun materi pembelajaran. Sedangkan menurut Anderson (1987) tujuan dari pembelajaran menggunakan media video yaitu mencakup tujuan kognitif, afektif dan psikomotor. Tujuan Kognitif diantaranya : (1). Dapat mengembangkan kemampuan kognitif yang menyangkut kemempuan mengenal kembali dan kemampuan memberikan rangsangan berupa gerak dan sensasi; (2). Dapat mempertunjukkan serangkaian gambar diam tanpa suara sebagaimana media foto dan film bingkai meskipun kurang ekonomis; (3). Video dapat digunakan untuk menunjukkan contoh cara bersikap atau berbuat dalam suatu penampilan, khususnya menyangkut interaksi manusiawi. Tujuan Afektif bahwa video dapat memjadi media yang sangat baik dalam mempengaruhi sikap dan emosi. Sedangkan tujuan psikomotor yaitu Video 
merupakan media yang tepat untuk memperlihattkan contoh ketrampilan yang menyangkut gerak. Berdasarkan data hasil análisis bahwa 94\% menyatakan bahwa media video pembelajaran sangat membantu dalam memperoleh materi sedangkan 6\% menyatakan tidak. Menurut Anderson (1987) media video memiliki kelebihan antara lain : (1). Dengan menggunakan video (disertai suara atau tidak), kita dapat menunjukkan kembali Gerakan tertentu; (2). Dengan menggunakan efek tertentu dapat diperkokoh baik proses belajar maupun nilai hiburan dari penyajian itu; (3). Dengan video, informasi dapat disajikan secara serentak pada waktu yang sama di lokasi (kelas) yang berbeda dan dengan jumlah penonton atau peserta yang tak terbatas dengan jalan menempatkan monitor di setiap kelas; (4). Dengan video siswa dapat belajar secara mandiri. Berdasarkan data hasil análisis bahwa $94 \%$ menyatakan media vidio pembelejaran sangat berperan sedangkan $6 \%$ menyatakan tidak. Penerapan media video pembelajaran sangat berperan digunakan dalam proses pembelajaran secara daring dimasa Pandemi Covid-19. Menurut Prastowo (2012) bahwa manfaat penggunaan media video antara lain: (1). Memberikan pengalaman yang terduga kepada peserta didik; (2). Memperlihatkan secara nyata sesuatu yang pada awalnya tidak mungkin bisa dilihat; (3). Menganalisis perubahan dalam periode waktu tertentu; (4). Memberikan pengalaman kepada peserta didik untuk merasakan suatu keadaan tertentu; (5). Menampilkan presentasi studi kasus tentang kehidupan sebenarnya yang dapat memicu diskusi peserta didik. Berdasarkan data hasil análisis bahwa 94\% mengikuti proses pembelajaran melalui media video pembelejaran sedangkan $6 \%$ tidak mengikuti karena tidak memiliki handphone. Saat ini, guru harus berkompeten dan handal di era teknologi, agar dapat berperan secara optimal dimana guru dituntut memiliki kecakapan dan keahlian termasuk dalam penggunaan IT Hal ini sebagaimana yagn diungkapkan oleh Nugroho (2012) bahwa guru harus berkompeten dan handal di era teknologi, agar dapat berperan secara optimal dimana guru dituntut memiliki kecakapan dan keahlian termasuk dalam penggunaan IT. Berdasarkan data hasil análisis menunjukkan bahwa $94 \%$ menjawab peertanyaan melalui media vidio pembelejaran sedangkan $6 \%$ tidak mengikuti media vidio pembelejaran. Berdasarkan data hasil análisis bahwa 94\% aktif bertanya melalui media vidio pembelejaran sedangkan 6\% tidak aktif disebabkan karana tidak memiliki handphone. Berdasarkan data hasil análisis bahwa $94 \%$ belajar melalui daring lebih mudah dari pada luring sedangkan $6 \%$ belajar melalui daring itu lebih sulit. Keberhasilan guru dalam melakukan pembelajaran daring pada situasi pandemi Covid-19 terletak pada kemampuan guru dalam merancang, dan menyusun materi, metode pembelajaran, dan aplikasi apa yang sesuai dengan materi dan metode. Kreatifitas merupakan kunci sukses dari seorang guru untuk dapat memotivasi siswanya tetap semangat dalam belajar secara daring. Berdasarkan data hasil análisis bahwa $94 \%$ orang tua peserta didik mendampingi anaknya belajar secara daring sedangkan $6 \%$ sulit mendampingi anaknya pada proses belajar scara daring yang disebabkan karena tida memiliki handphone. Dimasa Pandemi Covid-19, peran oang tua terhadap anak dirumah dalam mendampingi proses belajas sangat tinggi. Menurut Badudu (2019) bahwa kualitas komunikasi orang tua dan anak yang semakin baik akan meningkatkan kepercayaan anak terhadap orang tuanya. Berdasarkan data hasil análisis bahwa 94\% dalam proses pembelajaran seacara daring menggunakan handphone sedangkan 6\% tidak menggunakan handphone. Ini menunjukkan bahwa pentingnya media komunikasi dan teknologi seperti handphone dalam melaksanakan pembelajaran secara daring. Melalui teknologi inilah satu-satunya jembatan yang dapat menghubungkan guru dan siswa dalam pembelajaran dimasa Pandemi Covid-19. Guru dituntut untuk mampu menggunakan media komunikasi dan teknologi sebagai syarat mutlak untuk melaksanakan pembelajaran secara daring. Hal ini sebagaimana yang diungkapkan oleh Simarmata et al. $(2019,2020)$ bahwa kemampuan untuk menggunakan media komunikasi dan teknologi menjadi syarat mutlak untuk melaksanakan pembelajaran secara daring. Berdasarkan data hasil análisis bahwa 32\% dalam proses pembelajaran seacara daring menggunakan Laptop/komputer sedangkan $68 \%$ tidak menggunakan 
Laptop/komputer. Ketersediaan sarana belajar merupakan faktor penting dalam menunjang keberhasilan proses pembelajaran dimasa Pandemi Covid-19. Salah satu sarana pendukung dalam media video pembelajaran adalah laptop atau komputer. Menurut Simanihuruk et al. (2019) kegiatan daring diantaranya Webinar, kelas online, seluruh kegiatan dilakukan menggunakan jaringan internet dan computer. Berdasarkan data hasil análisis bahwa 94\% menggunakan kuota belajar sedangkan $6 \%$ peserta didik tidak menggunakan kuota belajar. Berdasarkan data hasil análisis bahwa 32\% mempunyai jaringan wifi di rumah sedangkan $68 \%$ tidak tersedia jaringan wifi di rumah. Berdasarkan data hasil análisis bahwa 94\% menyatakan jaringan internet merupakan faktor permasalahan sedangkan $6 \%$ menyatakan jaringan internet bukan merupakan faktor permasalahan. Pembelajaran daring tidak bisa lepas dari jaringan internet. Pembelajaran daring merupakan bentuk penyampaian pembelajaran konvensional yang dituangkan pada format digital melalui internet. Hal ini sebagaimana yagn diungkapkan oleh Imania (2019) pembelajaran daring merupakan bentuk penyampaian pembelajaran konvensional yang dituangkan pada format digital melalui internet. Namun kenyataannya bahwa, jaringan internet merupakan salah satu faktor yang dapat menghambat proses pembelajaran peserta didik secara daring dimasa Pandemi Covid-19. Koneksi jaringan internet menjadi salah satu kendala yang dihadapi. Hal ini yang menjadi permasalahan yang begitu banyak terjadi pada peserta didik yang mengikuti pembelajaran daring sehingga kurang optimal pelaksanaannya pembelajaran baik terhadap guru maupun pesera didik. Berdasarkan data hasil análisis bahwa 94\% menyatakan bahwa guru mengajar sesuai dengan tujuan pembelajaran sedangkan $6 \%$ tidak. Salah satu upaya guru dalam menciptakan pembelajaran dimasa Pandemi Covid-19 adalah dengan menggunakan suatu model pembelajaran untuk mencapai suatu tujuan. Menurut Rusman (2012:133) bahwa model merupakan pola umum perilaku pembelajaran untuk mencapai tujuan yang diharapkan. Berdasarkan data hasil análisis bahwa $94 \%$ menyatakan guru mengajar tepat waktu sedangkan 6\% menyatakan guru mengajar tidak tepat waktu. Dimasa Pandemi Covid-19, guru tetap dituntut disiplin dan menjalakan pendidikan di sekolah. Pembelajaran diharuskan tetap berlangsung agar pendidikan terjamin. Guru juga dituntut untuk kreativitasnya sebagai fasilitator dalam pembelajaran. Berdasarkan data hasil análisis bahwa 94\% menyatakan guru merefleksi akhir pelajaran sedangkan 6\% menyatakan guru tidak merefleksi akhir pelajaran. Berikut tabel Data Persentase Hasil Vidio Pembelaajran Terhadap Peserta Didik:

Tabel 3. Data Persentase Hasil Vidio Pembelaajran Terhadap Peserta Didik

\begin{tabular}{|c|c|c|c|}
\hline \multirow[t]{2}{*}{ NO. } & \multirow[t]{2}{*}{ URAIAN } & \multicolumn{2}{|c|}{$\begin{array}{l}\text { PERSENTASE } \\
\text { (\%) PERNYATAAN } \\
\text { PESERTA DIDIK }\end{array}$} \\
\hline & & TIDAK & YA \\
\hline 1 & $\begin{array}{l}\text { Jumlah peserta didik yang di absen melalui media video } \\
\text { pembelajaran }\end{array}$ & $6 \%$ & $94 \%$ \\
\hline 2 & $\begin{array}{l}\text { Jumlah peserta didik yang menyatakan Pelajaran IPS pelajaran } \\
\text { yang di sukai }\end{array}$ & $23 \%$ & $77 \%$ \\
\hline 3 & $\begin{array}{l}\text { Jumlah peserta didik yang menyatakan belajar IPS melalui media } \\
\text { video pembelajaran lebih mudah }\end{array}$ & $35 \%$ & $65 \%$ \\
\hline 4 & $\begin{array}{l}\text { Jumlah peserta didik yang menyatakan materi pelajaran yang } \\
\text { diberikan melalui media video pembelajaran sangat jelas }\end{array}$ & $6 \%$ & $94 \%$ \\
\hline 5 & $\begin{array}{l}\text { Jumlah peserta didik yang menyatakan peran media video } \\
\text { pembelajaran sangat membantu dalam memperoleh materi } \\
\text { secara daring }\end{array}$ & $6 \%$ & $94 \%$ \\
\hline 6 & $\begin{array}{l}\text { Jumlah peserta didik yang jarang mengikuti pembelajaran } \\
\text { melalui media video pembelajaran }\end{array}$ & $94 \%$ & $6 \%$ \\
\hline
\end{tabular}


Vol. 1 No. 2 September 2021, e-ISSN : 2797-8842 | p-ISSN : 2797-9431

\begin{tabular}{|c|l|c|c|}
\hline 7 & $\begin{array}{l}\text { Jumlah peserta didik yang dapat menjawab pertanyaan melalui } \\
\text { media video pembelajaran }\end{array}$ & $6 \%$ & $94 \%$ \\
\hline 8 & Jumlah peserta didik yang bertanya melalui daring & $6 \%$ & $94 \%$ \\
\hline 9 & $\begin{array}{l}\text { Jumlah peserta didik yang menyatakan belajar IPS melalui } \\
\text { daring lebih sulit dari pada belajar secara luring }\end{array}$ & $94 \%$ & $6 \%$ \\
\hline 10 & $\begin{array}{l}\text { Jumlah peserta didik yang di dampingi orang tua saat mengikuti } \\
\text { media video pembelajaran }\end{array}$ & $6 \%$ & $94 \%$ \\
\hline 11 & Jumlah peserta didik belajar daring menggunakan handphone & $68 \%$ \\
\hline 12 & $\begin{array}{l}\text { Jumlah peserta didik belajar daring menggunakan laptop } \\
\text { (Komputer) }\end{array}$ & $\begin{array}{l}\text { Jumlah peserta didik yang menggunakan kuota belajar sebagai } \\
\text { sarana belajar daring }\end{array}$ & $64 \%$ \\
\hline 14 & $\begin{array}{l}\text { Jumlah peserta didik yang tersedia jaringan wifi di rumah } \\
\text { sebagai sarana belajar daring }\end{array}$ & $68 \%$ \\
\hline 15 & $\begin{array}{l}\text { Jumlah peserta didik yang menyatakan jaringan internet menjadi } \\
\text { faktor permasalahan pada media video pembelajaran }\end{array}$ & $6 \%$ \\
\hline 16 & $\begin{array}{l}\text { Jumlah peserta didik yang menyatakan guru mengajar sesuai } \\
\text { dengan tujuan pembelajaran }\end{array}$ & $6 \%$ & $94 \%$ \\
\hline 17 & $\begin{array}{l}\text { Jumlah peserta didik yang menyatakan guru mengajar tepat } \\
\text { waktu }\end{array}$ & $6 \%$ & $94 \%$ \\
\hline 18 & $\begin{array}{l}\text { Jumlah peserta didik yang menyatakan guru merefleksi akhir } \\
\text { pelajaran }\end{array}$ & $6 \%$ & $94 \%$ \\
\hline
\end{tabular}

3. Mengevaluasi data peserta didik terhadap media video pembelajaran dimasa Pandemi Covid-19

Pada tahap ketiga, guru melakukan evaluasi terhadap hasil pembelajaran melalui media video pembalajaran. Berikut tabel hasil pembelajaran melalui media video pembelajaran :

Tabel 4. Data Analisis Hasil Video Pembelajaran Terhadap Peserta Didik

\begin{tabular}{|c|c|c|c|c|c|c|}
\hline \multirow{3}{*}{ NO. } & \multirow{3}{*}{ URAIAN } & \multicolumn{4}{|c|}{ PERENTASE } & \multirow{3}{*}{ KETERANGAN } \\
\hline & & \multicolumn{2}{|c|}{$\begin{array}{c}\text { PRA VIDIO } \\
\text { PEMBELAJARAN }\end{array}$} & \multicolumn{2}{|c|}{$\begin{array}{l}\text { SETELAH VIDIO } \\
\text { PEMBELAJARAN }\end{array}$} & \\
\hline & & TIDAK & YA & TIDAK & YA & \\
\hline 1 & $\begin{array}{l}\text { Jumlah Tidak peserta didik } \\
\text { yang di absen melalui media } \\
\text { video pembelajaran }\end{array}$ & $6 \%$ & $94 \%$ & $6 \%$ & $94 \%$ & $\begin{array}{l}\text { Semua peserta } \\
\text { didik hadir }\end{array}$ \\
\hline 2 & $\begin{array}{ll}\text { Jumlah peserta didik yang } \\
\text { menyatakan Pelajaran } & \text { IPS } \\
\text { pelajaran yang di sukai } & \end{array}$ & $58 \%$ & $42 \%$ & $23 \%$ & $77 \%$ & $\begin{array}{c}\text { Terjadi } \\
\text { peningkatan } \\
35 \%\end{array}$ \\
\hline 3 & $\begin{array}{l}\text { Jumlah siswa yang menyatakan } \\
\text { belajar IPS melalui media video } \\
\text { pembelajaran lebih mudah }\end{array}$ & $58 \%$ & $42 \%$ & $35 \%$ & $65 \%$ & $\begin{array}{c}\text { Terjadi } \\
\text { peningkatan } \\
23 \%\end{array}$ \\
\hline 4 & $\begin{array}{l}\text { Jumlah peserta didik yang } \\
\text { menyatakan materi pelajaran } \\
\text { yang diberikan melalui media } \\
\text { video pembelajaran sangat jelas }\end{array}$ & $58 \%$ & $42 \%$ & $6 \%$ & $94 \%$ & $\begin{array}{c}\text { Terjadi } \\
\text { peningkatan } \\
52 \%\end{array}$ \\
\hline 5 & $\begin{array}{l}\text { Jumlah peserta didik yang } \\
\text { menyatakan pembelajaran } \\
\text { sebelum menggunakan media }\end{array}$ & $58 \%$ & $42 \%$ & $6 \%$ & $94 \%$ & $\begin{array}{c}\text { Terjadi } \\
\text { peningkatan } \\
52 \%\end{array}$ \\
\hline
\end{tabular}


Vol. 1 No. 2 September 2021, e-ISSN : 2797-8842 | p-ISSN : 2797-9431

\begin{tabular}{|c|c|c|c|c|c|c|}
\hline & $\begin{array}{l}\text { video pembelajaran sangat } \\
\text { membantu dalam memperoleh } \\
\text { materi }\end{array}$ & & & & & \\
\hline 6 & $\begin{array}{l}\text { Jumlah peserta didik yang } \\
\text { pernah tidak mengikuti } \\
\text { pembelajaran melalui media } \\
\text { video }\end{array}$ & $61 \%$ & $39 \%$ & $77 \%$ & $23 \%$ & $\begin{array}{c}\text { Terjadi } \\
\text { peningkatan } \\
16 \%\end{array}$ \\
\hline 7 & $\begin{array}{l}\text { Jumlah peserta didik yang dapat } \\
\text { menjawab pertanyaan melalui } \\
\text { pembelajaran daring }\end{array}$ & $81 \%$ & $19 \%$ & $6 \%$ & $94 \%$ & $\begin{array}{c}\text { Terjadi } \\
\text { peningkatan } \\
75 \%\end{array}$ \\
\hline 8 & $\begin{array}{l}\text { Jumlah peserta didik yang } \\
\text { bertanya melalui daring }\end{array}$ & $19 \%$ & $81 \%$ & $6 \%$ & $94 \%$ & $\begin{array}{c}\text { Terjadi } \\
\text { peningkatan } \\
13 \%\end{array}$ \\
\hline 9 & $\begin{array}{l}\text { Jumlah peserta didik yang } \\
\text { menyatakan belajar IPS melalui } \\
\text { daring lebih sulit dari pada } \\
\text { belajar secara luring }\end{array}$ & $84 \%$ & $16 \%$ & $94 \%$ & $6 \%$ & $\begin{array}{c}\text { Terjadi } \\
\text { peningkatan } \\
10 \%\end{array}$ \\
\hline 10 & $\begin{array}{l}\text { Jumlah peserta didik yang di } \\
\text { dampingi orang tua saat } \\
\text { mengikuti media } \\
\text { pembelajaran }\end{array}$ & $58 \%$ & $42 \%$ & $6 \%$ & $94 \%$ & $\begin{array}{c}\text { Terjadi } \\
\text { peningkatan } \\
10 \%\end{array}$ \\
\hline 11 & $\begin{array}{ll}\text { Jumlah peserta didik belajar } \\
\text { daring } & \text { menggunakan } \\
\text { handphone } & \end{array}$ & $6 \%$ & $94 \%$ & $6 \%$ & $94 \%$ & $\begin{array}{l}\text { Tidak terjadi } \\
\text { peningkatan }\end{array}$ \\
\hline 12 & $\begin{array}{l}\text { Jumlah peserta didik belajar } \\
\text { daring menggunakan laptop } \\
\text { (Komputer) }\end{array}$ & $84 \%$ & $16 \%$ & $68 \%$ & $32 \%$ & $\begin{array}{c}\text { Terjadi } \\
\text { peningkatan } \\
16 \% \\
\end{array}$ \\
\hline 13 & $\begin{array}{l}\text { Jumlah peserta didik yang } \\
\text { menggunakan kuota belajar } \\
\text { sebagai sarana belajar daring }\end{array}$ & $6 \%$ & $94 \%$ & $6 \%$ & $94 \%$ & $\begin{array}{l}\text { Tidak terjadi } \\
\text { peningkatan }\end{array}$ \\
\hline 14 & $\begin{array}{l}\text { Jumlah peserta didik yang } \\
\text { tersedia jaringan wifi di rumah } \\
\text { sebagai sarana belajar daring }\end{array}$ & $84 \%$ & $16 \%$ & $68 \%$ & $32 \%$ & $\begin{array}{c}\text { Terjadi } \\
\text { peningkatan } \\
16 \%\end{array}$ \\
\hline 15 & $\begin{array}{l}\text { Jumlah peserta didik yang } \\
\text { menyatakan jaringan internet } \\
\text { menjadi faktor permasalahan } \\
\text { pada media video pembelajaran }\end{array}$ & $6 \%$ & $94 \%$ & $6 \%$ & $94 \%$ & $\begin{array}{l}\text { Tidak terjadi } \\
\text { peningkatan }\end{array}$ \\
\hline 16 & $\begin{array}{l}\text { Jumlah peserta didik yang } \\
\text { menyatakan guru mengajar } \\
\text { sesuai dengan } \\
\text { pembelajaran }\end{array}$ & $6 \%$ & $94 \%$ & $6 \%$ & $94 \%$ & $\begin{array}{l}\text { Tidak terjadi } \\
\text { peningkatan }\end{array}$ \\
\hline 17 & $\begin{array}{l}\text { Jumlah peserta didik yang } \\
\text { menyatakan guru mengajar } \\
\text { tepat waktu }\end{array}$ & $6 \%$ & $94 \%$ & $6 \%$ & $94 \%$ & $\begin{array}{l}\text { Tidak terjadi } \\
\text { peningkatan }\end{array}$ \\
\hline 18 & $\begin{array}{l}\text { Jumlah peserta didik yang } \\
\text { menyatakan guru merfleksi } \\
\text { akhir pelajaran }\end{array}$ & $6 \%$ & $94 \%$ & $6 \%$ & $94 \%$ & $\begin{array}{l}\text { Tidak terjadi } \\
\text { peningkatan }\end{array}$ \\
\hline
\end{tabular}

Hasil menunjukkan bahwa media video pembelajaran dapat membantu guru menyampaikan materi dan menciptakan situasi pembelajaran yang tidak monoton. Penelitian yang relevan terhadap hasil analisis ini adalah penelitian yang dilakukan oleh Miftahul Khairani, dkk. (2019) Studi Meta-Analisis Pengaruh Video Pembelajaran Terhadap 
Hasil Belajar Peserta Didik. Dosen Program Pascasarjana Pendidikan Biologi, Universitas Negeri Yogyakarta. Penelitian ini memberikan kesimpulan bahwa media pembelajaran video dapat memudahkan bagi para pendidik dalam melakukan kegiatan belajar. Dengan penampilan video pembelajaran yang menarik mulai dari penyajian isi mengunakan audio dan visual yang berisi pesan-pesan materi, sehingga membantu peserta didik dalam memahami materi pembelajaran yang disampaikan. Video pembelajaran yang dapat digunakan dan dapat dibuka kapanpun bagi peserta didik, sehingga dapat meningkatkan hasil belajar bagi peserta didik.

Hasil menunjukkan bahwa media video pembelajaran dapat membantu peserta didik untuk memahami materi pelajaran dan menyelesaikan tugas yang di berikan guru. Penelitian yang relevan terhadap fakta data diatas adalah penelitian yang dilakukan oleh Penelitian yang dilakukan oleh Arif Yudianto (2017) Penerapan Video Sebagai Media Pembelajaran. Program Studi Pendidikan Tekenologi Informasi, Universitas Muhammadiyah Sukabumi, memberikan kesimpulan bahwa media video merupakan media pembelajaran yang paling tepat dan akurat dalam menyampaikan pesan dan akan sangat membantu pemahaman peserta didik. Dengan adanya media video, peserta didik akan lebih paham dengan materi yang disampaikan pendidik melalui tayangan sebuah film yang diputarkan.

Hasil menunjukkan bahwa media video pembelajaran yang layak dan efektif dalam meningkatkan motivasi dan hasil belajar bagi peserta didik dimasa Pandemi Covid-19. Penelitian yang relevan terhadap hasil data ini adalah penelitian yang dilakuan oleh Hanani (2021) Pemanfaatan Media Pembelajaran Berbasis Video Sebagai Alternatif dalam Pembelajaran Daring IPA DI MTs. Negeri 1 OKU Timur Sumatera Selatan. Penelitian ini memberikan kesimpulan bahwa pembelajaran daring IPA dengan memanfaatkan media pembelajaran yang berbasis video telah saya praktekkan di kelas VIII tahun pelajaran 2020/2021. Berdasarkan hasil penelitian di kelas VIII.1 s/d VIII.7 sebelum menggunakan video minat dan motivasi belajar hanya $21,4 \%$ atau 48 siswa dengan memanfaatkan media yang berbasis video minat dan motivasi peserta didik meningkat menjadi 79,5\% atau 178 siswa. Dengan peningkatan minat dan motivasi siswa dalam pembelajaran daring dengan media video tersebut, setidaknya telah mewakili guru dalam memberikan pengajaran yang sesuai dengan kebutuhan siswa di masa Pandemi Covid-19 .

Penelitian yang relevan terhadap fakta data ini adalah penelitian yang dilakukan oleh Adi Prehanto (2021) Video Pembelajaran Interaktif-Animatif sebagai Media Pembelajaran IPS SD Kelas Tinggi di Masa Pandemi Covid 19. Universitas Pendidikan Indonesia. Penelitian ini memberikan kesimpulan bahwa penggunaan video pembelajaran yang animatif-interaktif efektif sebagai media pembelajaran, terutama di masa pandemic Covid 19. Melalui pemanfaatan video pembelajaran interaktif, sebagian besar siswa memiliki ketertarikan, dimana video pembelajaran animatif-interaktif membantu belajar di rumah.

\section{KESIMPULAN}

Berdasarkan hasil dan pembahasan diatas, maka pelaksanaan kegiatan penggunaan media video pembelajaran pembelajaran jarak jauh di masa pandemi Covid-19, hasil menunjukkan bahwa terselenggaranya proses belajar jarak jauh di masa Pandemi Covid-19 melalui video pembelajaran.

\section{DAFTAR PUSTAKA}

A.Cahyadi.(2019). Pengembangan Media dan Sumber Belajar: Teori dan Prosedur.

Adi Prehanto.( 2021). Video Pembelajaran Interaktif-Animatif sebagai Media Pembelajaran IPS SD Kelas Tinggi di Masa Pandemi Covid 19. Universitas Pendidikan Indonesia.

Amanah, S. (2016). Pedagogi: Media Pembelajaran Kimia-SMA. Bandung: PPPPTK IPA.

Anderson, Ronald H. (1987). Pemilihan dan Pengembangan Media untuk Pembelajaran. Jakarta: Universitas Terbuka bekerja sama dengan CV. Rajawali.

Anisa, F., \& Yuliyanto, E. (2017). Analisis Faktor yang Mempengaruhi Pembelajaran Kimia di SMA Teuku Umar. Semarang: In Prosiding Seminar Nasional \& Internasional. 
Ardana, I Made. (2008). Peningkatan Kualitas Belajar Siswa melalui Pengembangan Pembelajaran Matematika berorientasi Gaya Kognitif dan Berwawasan Konstruktivis. Salatiga: Jurusan Pendidikan Matematika FMIPA UNDIKSYA.

Arif Yudianto. (2017). Penerapan Video Sebagai Media Pembelajaran. Program Studi Pendidikan Tekenologi Informasi, Universitas Muhammadiyah Sukabumi.

Astaman, dkk. (2018). Upaya Mengatasi Kejenuhan Belajar. Universitas Muhammadiyah Palu. Badudu, R. (2019). Character Exellence; Mengembangkan Karakter Anak, Siswa, dan Karyawan 2. Jakarta: Penerbit Buku Kompas.

Cheppy Riyana. (2007). Pedoman Pengembangan Media Video, P3AI UPI . Jakarta.

Darmadi. (2017). Pengembangan Model dan Metode Pembelajaran dalam Dinamika Belajar Siswa. Sleman: Penerbit Depublish.

Edy Saputra. (2020). Snowballa Thorowing Tiongkok Minat dan Hasil belajar. Sukabumi: Haura Publising.

Emzir. (2007). Metodologi Penelitian Pendidikan Kuantitatif dan Kualitatif. Jakarta:PT Raja Grafindo Persada.

Hanani. (2021). Pemanfaatan Media Pembelajaran Berbasis Video Sebagai Alternatif dalam Pembelajaran Daring IPA DI MTs. Negeri 1 OKU Timur Sumatera Selatan.

Haswan, Elly. (2006). Pengaruh Metoda Pembelajaran terhadap Hasil Belajar Fisika ditinjau dari Gaya Kognitif Siswa (Eksperiment pada Kelas XI Jurusan IPA MAN Insan Cendekia Serpong Banten) . Jakarta: Program Pasca Sarjana UNJ.

Herman, Yudi. (2005). Pengaruh Umpan Balik Tes Formatif dan Gaya Kognitif terhadap Hasil Belajar Mata Kuliah Statistika (Studi Kasus pada Mahasiswa Jurusan PAI UNISMA Bekasi). Jakarta: Program Pasca Sarjana UNJ.

Imania, Kuntum An Nisa. (2019). Rancangan Pengembangan Instrumen Penilaian Pembelajaran Berbasis Daring. Jurnal PETIK. Vol 5, 31-47.

Miftahul Khairani, dkk. (2019). Studi Meta-Analisis Pengaruh Video Pembelajaran Terhadap Hasil Belajar Peserta Didik. Dosen Program Pascasarjana Pendidikan Biologi. Universitas Negeri Yogyakarta.

Moh. Ayip S. (2003). Efektivitas Penggunaan Media Video Animasi dalam Proses Pembelajaran Fisika. Diterbitkan, Bandung. hlm.65.

Mulyadi. (2010). Diagnosis Kesulitan Belajar Dan Bimbingan Kesulitan Belajar Khusus. Yogyakarta : Nuha Litera.

Mulyasa, E. (2013). Pengembangan dan implementasi kurikulum 2013. PT. Remaja Rosdakarya.

Musmirotun Khasanah. (2021). Jurnal Peran Orang Tua Dalam Pembelajaran Daring Anak USIA DINI Kelompok B di RA DIPONEGORO 1 Kutawis Kecamatan Bukateja Kabupaten Purbalingga. Program Studi Pendidikan Islam Anak Usia Dini Fakultas Tarbiyah dan Ilmu Keguruan Institut Agama Islam Negeri (IAIN) Purwokerto.

Nasution, S dan Supriyadi. (2007). Pengaruh Urutan Bukti, Gaya Kognitif, dan Personalitas terhadap Proses Revisi Keyakinan. Makassar: Simposium Nasional Akuntansi X, UNHAS.

Nugroho, S. (2012). Profesionalisme Guru SD Negeri Se-Kecamatan Warungasem Kabupaten Batang. Varia Pendidikan, 24 (2), 135-146.

Peraturan Menteri Pendidikan dan Kebudayaan Republik Indonesia Nomor 719/P/2020 tentang Pedoman Pelaksanaan Kurikulum pada Satuan Pendidikan dalam Kondisi Khusus, pelaksanaan kurikulum 13 berubah menjadi kurikulum secara khusus.

Prastowo, Andi. (2012). Panduan Kreatif Mambuat Bahan Ajar Inovatif.Yogyakarta: Diva Press.

Putra,dkk. (2013). Hubungan Gaya Kognitif dan Penalaran Verbal dengan Prestasi Belajar Mata Kuliah Anatomi II pada Mahasiswa Pendidikan Jasmani Kesehatan dan Rekreasi (Fakultas Olahraga Dan Kesehatan Universitas Pendidikan Ganesha). Jurnal Magister Kedokteran Keluarga, Volume 1 No. 1 pp. 92-103. 
Rahman, Ulfiani. (2007). Mengenal Burnout pada Guru.Jurnal Lentera Pendidikan. Edisi X No. 2.

Rahmasari, Gartika \& Rita Rismiati. (2013). E-Learning Pembelajaran Jarak Jauh untuk SMA. Bandung: Yrama Widya.

Rusman. (2012). Model-model Pembelajaran Mengembangkan Profesionalisme Guru. Jakarta: Rajawali Pers

Saragih, E. M., \& Ansi, R. Y. (2020). Efektivitas Penggunaan Whatsapp Group Selama Pandemi Covid-19 Bagi Pelaku Pendidik. In Seminar Nasional Multi Disiplin Ilmu Universitas.

Sari, N. L. (2020). Pelatihan Model Pembelajaran Jarak Jauh Berbasis Google Form Sebagai Media Pembela. KOMMAS: Jurnal Pengabdian Kepada Masyarakat, 1(2).

Simanihuruk, et al. (2019). E-Learning: Implementasi, Strategi dan Inovasinya (T. Limbong (ed.); 1 st ed.)). Yayasan Kita Menulis.

Simarmata, J. et al. (2019). Inovasi Pendidikan Lewat Transpormasi Digital. Medan: Yayasan Kita Menulis.

Simarmata, J. et al. (2020). Pendidikan Di Era Revolusi 4.0: Tuntutan, Kompetensi \& Tantangan. Medan: Yayasan Kita Menulis.

Slamato. (2015). Belajar dan Faktor-faktor yang mempengaruhinya. Bandung: Rineka Cipta.

Subini N. (2016). Mengatasi Kesulitan Belajar Pada Anak. Yogyakarta : Buku Kita.

Sugihartono, dkk. (2007). Psikologi Pendidikan. Yogyakarta: UNY Press.

SuratEdaran Menteri Pendidikan dan Kebudayaan Republik Indonesia Nomor4 Tahun 2020 Tentang Pelaksanaan Kebijakan Pendidikan Dalam Masa Darurat Penyebaran Corona Virus Disease (COVID- 19).

Surat Edaran Menteri Pendidikan dan Kebudayaan Republik Indonesia Nomor 15 Tahun 2020 tentang Pedoman Penyelenggaraan Belajar Dari Rumah Dalam Masa Darurat Penyebaran Corona Virus Desese (COVID-19).

Thamrin, Husni. (2008). Panduan Penggunaan Layanan Google (Google Form).

Vitasari, Ita. (2016). Kejenuhan (Burnout) Belajar di Tinjau dari Tingkat Kesepian dan Kontrol Diri pada Siswa kelas XI SMA Negeri 9 Yogyakarta. Skripsi. Universitas Negeri Yogyakarta.

Yulia, Djahir. (2015). Perencanaan dan Media Pembelajaran. Yogyakarta: Talenta Indonesia Mandiri. 